\title{
PENDIDIKAN PROFETIK; Mengenal Gagasan Ilmu Sosial Profetik Kuntowijoyo
}

\author{
Masduki
}

Institute Agama Islam Sunan Giri Ponorogo

masduki_gtg@yahoo.co.id

\begin{abstract}
Abstrak
This study is a further examination on prophetic paradigm developed by Kuntowijoyo, then it is implemented as a basis in Islamic learning. According to Kuntowijoyo, there are three basic pillars in developing this prophetic mission, humanism, liberation, and transcendence. Furthermore, its implications are, first, making prophetic education values as an effort to create Islamic education which is full of love, tolerance, righteousness, respecting the differences and other humanitarian characteristics. Second, Islamic education should follow the mission of Mubammad PBUH as a model in the learning processes. It should refer to Islamic education which teaches wisdom; each human behavior is based on God 's rules. Third, science should not be dichotomist. All sciences must have universal values. Therefore, objectification in viewing a science is crucial.
\end{abstract}

Keywords: Islam, Sekretarianisme, dan Komunalisme

\section{Pendahuluan}

Secara

normatif-konseptual, paradigma pendidikan profetik Kuntowijoyo (2005) didasarkan pada Surah Ali-Imran ayat 110 yang artinya: "Engkau adalah ummat terbaik yang diturunkan/dilabirkan di tengah-tengah manusia untuk menyurub kepada yang ma'ruf dan mencegah kemunkaran dan beriman kepada Allab".

Berdasarkan ayat tersebut, terdapat tiga pilar utama yang mendasari munculnya pendidikan profetik yaitu; amar ma'ruf (bumanisasi) yang mengandung pengertian memanusiakan manusia, kemudian nabi munkar (liberasi) mengandung pengertian pembebasan, dan tu'minunu billah (transendensi), dimensi keimanan manusia.

Tiga konsep tersebut, menjadi prasyarat bagi umat muslim untuk menjadi ummat terbaik (The Chosen People). Ummat Islam tidak secara otomatis menjadi The Chosen People, karena ummat Islam dalam konsep ayat tersebut mensyaratkan akan adanya sebuah tantangan untuk bekerja lebih keras dan ber-fastabiqul khairat. Ayat diatas juga menegaskan akan adanya aktivisme atau praksisme gerakan sejarah. Bekerja keras dan ber-fastabiqul khairat ditengah-tengah ummat manusia (ukhrijat Linnas) berarti bahwa yang ideal bagi Islam adalah keterlibatan ummat dalam percaturan sejarah. Pengasingan 
diri secara ekstrim dan kerahiban tidak dibenarkan dalam Islam. Para intelektual yang hanya bekerja untuk ilmu atau kecerdasan an sich tanpa menyapa dan bergelut dengan realitas sosial juga tidak dibenarkan.

Dalam konteks inilah, pendidikan agama Islam sebagai salah satu media penyadaran umat untuk menjadi "umat terbaik", sangat perlu menjadikan tiga pilar dalam ayat tersebut sebagai basis dalam pembelajaran. Konsep ini, mengharuskan pendidikan agama Islam pada pola pendidikan yang transformative, sebuah pola pendidikan yang mampu memberikan pemahaman dan transformasi pembelajaran yang tidak saja bertumpu pada transfer pengetahuan saja, tetapi juga transef nilai.

Pendidikan transformative juga menegasikan akan pola pembelajaran yang hanya berpusat pada guru (teacher centerd), tetapi lebih pada pola pembelajaran yang memberikan "ruang" bagi peserta didik untuk lebih mengaktualisasikan potensi akademisnya secara maksimal.

Salah satu usaha untuk mencoba melakukan perubahan dan pemaknaan terhadap pendidikan Islam yang berbasis pada humanisasi, liberasi, dan transendensi tersebut, menjadi penting untuk menjadikan pemikiran Kuntowijoyo, sebagai kunci dalam proses tersebut. Karena, gagasan tentang paradigma profetik dalam ilmuilmu sosial, dimotori olehnya. Selain itu, Kuntowijoyo juga mencoba mengupayakan sebuah konsep "pengilmuan islam", untuk menolak adanya dikotomi epistemologis antara Ilmu agama (akhirat) dan ilmu umum (dunia), antara Ilmu modern barat dan Ilmu tradisional Islam.

Bukunya yang terakhir Islam sebagai Ilmu (2004), menawarkan sebuah gagasan yang cukup mapan tentang proses "pengilmuan islam" bukan "islamisasi ilmu".

Tulisan ini merupakan kajian lebih jauh tentang paradigma profetik yang dibangun oleh Kuntowijoyo, kemudian dijadikan sebagai sebuah basis dalam pembelajaran pendidikan Islam.

\section{Sketsa Ringkas Perjalanan Hidup Kuntowijoyo}

Kuntowijoyo lahir di Sorobayan, Sanden, Bantul, Yogyakarta, pada 18 September 1943 (Fahmi, 2005). Akan tetapi, menurut Shofiyullah (2007), ia lahir di Desa Ngawonggo, Kecamatan Ceper, Kabupaten Klaten.

Ia merupakan anak kedua dari sembilan bersaudara dari pasangan suami-istri H. Abdul Wahid Sosroatmojo dan $\mathrm{Hj}$. Warasti yang berlatar belakang budaya Jawa santri dan berdarah bangsawan Jawa dari lingkungan Surakarta yang suka mendalang (seni). Sementara ayahnya, Haji Sosromartoyo, aktif mengurus masjid dan juga 
merupakan tokoh pimpinan Muhammadiyah di Yogyakarta. Sehingga, secara tidak langsung ia diasuh dalam kedalaman relijius dan seni sekaligus. Dua lingkungan yang sangat mempengaruhi pertumbuhannya semasa kecil dan remaja (Fahmi, 2005).

Masa kecil Kuntowijoyo adalah masa pergolakan, yaitu agresi Belanda tahun 1947 dan 1948. Pada tahun 1956, ia menamatkan Sekolah Rakyat (SR). Sejak kecil, ia aktif mengikuti kegiatankegiatan keagamaan, yaitu belajar agama ke surau yang dilakukan sehabis Dhuhur sepulang sekolah hingga selepas Ashar. Malamnya, sehabis Isya', ia kembali ke surau untuk mengaji (Fahmi, 2005).

Saat menjalani kehidupan surau inilah, Kuntowijoyo mulai belajar menulis puisi, berdeklamasi dan mendongeng. Di surau ini pula secara kebetulan ia mengenal Muhammadiyah, kemudian memasuki kepanduan Hiøbul Waton. Bakatnya dalam berdeklamasi, bermain drama, dan menulis puisi semakin berkembang ketika ia bergabung dalam organisasi Pelajar Islam Indonesia (PII) (Fahmi, 2005).

Selain belajar mengaji dan deklamasi, Kuntowijoyo gemar menyimak siaran sastra di Radio Republik Indonesia (RRI) Surakarta asuhan Mansur Samin dan Budiman S. Hartojo. Sehingga M. Saribi Arifin dan M.Yusmanam, mendorongnya untuk menulis sastra (Shofiyullah, 2007). Pada siang hari, ia sering menyempatkan diri pergi ke kota kecamatan, memasuki gedung perpustakaan dan melahap kisahkisah Karl May. Ketertarikannya pada dunia bacaan bertambah ketika ia belajar di SMP. Karya-karya Nugroho Notosusanto, Sitor Situmorang dan karya-karya sastrawan lain sudah ia baca. Sejak SMP inilah dia mulai menulis cerita dan sinopsis dengan tulisan tangan.

Selain sastra, seni dan agama, Kuntowijoyo, juga sangat berminat dengan kajian sejarah. Konon, saat belajar di madrasah ibtidaiyah di sebuah desa di Klaten, Jawa Tengah (19501956), Kunto kecil sangat kagum kepada guru mengajinya, ustad Mustajab, yang piawai menerangkan peristiwa tarikh (sejarah Islam) secara dramatik. Seolah dia dan murid-murid lainnya ikut mengalami peristiwa yang dituturkan Sang Ustad itu. Sejak itu, dia tertarik dengan sejarah (Susanto, 2003).

Tamat SMP (1959), ia pindah ke Solo dan sekolah SMA di sana. Kemudian Kuntowijoyo melanjutkan pendidikan formalnya pada Sekolah Menengah Atas di Surakarta dan diselesaikan pada tahun 1962. Di SMA ini, Kuntowijoyo sudah banyak membaca karya sastra, baik dari penulis Indonesia maupun dari luar negeri, seperti Karl May, Charles Dickens, dan Anton Chekov (Susanto, 2003).

Setelah lulu SMA pada tahun 1962, Kuntowijoyo melanjutkan pendidi- 
kannya di Jurusan Sejarah, Fakultas Sastra, Universitas Gadjah Mada (Shofiyullah, 2007). Di masa mahasiswa, bakat tulis menulisnya semakin berkembang. Berbagai tulisannya, baik berupa puisi, cerpen, novel, essai, dan naskah drama, bertebaran di berbagai media massa, seperti majalah Sastra, Horison, Kompas, Republika, Bernas, dan lainnya.

Pada tahun 1964, ketika ia masih menjadi mahasiswa, untuk pertama kalinya Kuntowijoyo menulis novel yang berjudul, Kereta Api yang Berangkat Pagi Hari, yang kemudian dimuat sebagai cerita bersambung di harian Djihad tahun 1966. Selain itu, ia juga menulis cerpen dan drama pendek untuk klubnya. Namun, ia baru memublikasikan karyanya itu pada pada tahun 1967 di majalah Horison (Shofiyullah, 2007). Kuntowijoyo juga aktif bahkan pendiri Leksi (Lembaga Kebudayan dan Seniman Islam) bersama kawankawannya sesama mahasiswa. Ia menjadi sekretaris tahun 1963-1969 (Sugarman, 2009).

Setelah Kuntowijoyo menamatkan studinya di UGM pada tahun 1969, kemudian, ia diangkat sebagai pengajar di almamaternya. Pada tahun 1967 Kuntowijoyo bertemu dengan Susilaningsih. Perempuan yang akrab dengan baju muslimah ini masih kuliah tingkat II di IAIN Sunan Kalijaga. Saat itu mereka secara kebetulan bertemu di Rumah Sakit Bethesda, Yogyakarta, tempat Kunto sedang dirawat karena penyakit batu ginjal. Pada saat itu, gadis asli Karanganyar, Jawa Tengah ini, sedang menjenguk temannya yang sakit dan dirawat di rumah sakit yang sama. Kemudian pada tanggal 8 November 1969, ia mempersunting dan menikahi Susilaningsih. Dari hasil perkawinannya, Kuntowijoyo dikaruniai 2 anak, yakni Punang Amaripuja dan Alun Paradipta (Sugarman, 2009).

Pada tahun-tahun 1969 pula, Kuntowijoyo mencoba aktif di beberapa kelompok studi keagamaan dan keislaman. Diantaranya adalah Kelompok Studi Mantika. Dari tahun 1969-1971 Kuntowijoyo aktif dalam kelompok tersebut bersama temannya, seperti M. Dawam Rahardjo, Arifin C. Noer, Abdul Hadi W.M., Amri Yahya, Sju'bah Asa, Chairul Umam, dan Ikranegara (Sugarman, 2009).

Ia juga aktif di Persatuan Islam Indonesia (PII) dan kelompok diskusi Limited Group. Selain itu, ada dua hal penting yang melatar belakangi pemikirannya terutama dalam merumuskan gagasan-gagasannya tentang Islam. Pertama, perhatiannya yang sangat besar terhadap pola pikir masyarakat yang masih dibelenggu mitos-mitos dan kemudian berkembang hanya sampai pada tingkat ideologi (Kuntowijoyo, 1984).

Menurutnya, Islam yang masuk ke Indonesia telah mengalami agrarisasi. 
Peradaban Islam yang bersifat terbuka, global, kosmopolit dan merupakan matarantai penting peradaban dunia telah mengalami penyempitan dan stagnasi dalam bentuk budaya-budaya lokal (Kuntowijoyo, 1994).

Untuk itu dia melakukan analisisanalisis historis dan kultural untuk melihat perkembangan umat Islam di Indonesia. Kondisi seperti ini telah mendorongnya untuk melontarkan gagasan-gagasan transformasi sosial melalui re-interpretasi nilai-nilai Islam, yang menurutnya sejak awal telah mendorong manusia berpikir secara rasional dan empiris (Kuntowijoyo, 1984).

Kedua, adanya respon terhadap tantangan masa depan yang cenderung mereduksi agama dan menekankan sekularisasi sebagai keharusan sejarah. Industrialisasi dan teknokratisasi akan melahirkan moralitas baru yang menekankan pada rasionalitas ekonomi, pencapaian perorangan dan kesamaan (Kuntowijoyo, 1994). Hal ini yang mendorong Kuntowijoyo untuk melontarkan gagasan tentang paradigma Islam, terutama yang berkaitan dengan rumusan teori ilmu-ilmu sosial Islam.

Gelar Masternya diperoleh di The University of Connecticut, Amerika Serikat, pada tahun 1974. Kemudian gelar doktor ilmu sejarah diperoleh dari Columbia University, New York, Amerika Serikat, pada tahun 1980 dengan judul disertasi
Social Change in an Agrarian Society: Madura1950-1940 (Kuntowijoyo, 1991), sudah diterjemahkan ke dalam bahasa Indonesia.

Pada tahun 1980, Kuntowijoyo membangun dan membina Pondok Pesantren Budi Mulia dan mendirikan Pusat Pengkajian Strategi dan Kebijakan (PPSK) di Yogyakarta. Meskipun sejak awal 1990 sepulang dari Belanda, ia menderita penyakit radang selaput otak (meningo enshephslitis), namun itu tak menjadi halangan baginya untuk terus menulis dan berkarya. Bahkan, berkat kemampuannya dalam menulis, tahun 1999 ia mendapatkan penghargaan satsra bergengsi di Asia Tenggara, yaitu SEA Write Award. Guru Besar Ilmu Budaya UGM inipun terus berkarya hingga detik-detik akhir hayatnya.

Pada hari Minggu, Kuntowijoyo berangkat tidur pukul 22.30. Rasa sakit di pinggang baru dirasakan pada pukul 24.00. Istrinya mencoba mengobati. Akan tetapi, pada pukul 03.00 Senin 21 Februari 2005, dia menderita diare. Lalu dia dibawa ke Rumah Sakit Sardjito. Sekitar pukul 20.00, kondisinya menurun dan harus dirawat di intensive care unit (ICU). Selasa 22 Februari 2005 pukul 16.00 dia menghembuskan nafas terakhir.

Beberapa Pilar Gagasan tentang Ilmu Sosial Profetik. 
Unsur pertama adalah humanisasi. Humanisasi merupakan terjemahan kreatif dari amar ma'ruf yang makna asalnya adalah menganjurkan atau menegakkan kebajikan. Dalam Ilmu Sosial Profetik, humanisasi artinya memanusiakan manusia, menghilangkan "kebendaan", ketergantungan, kekerasan dan kebencian dari manusia. Humanisasi sesuai dengan semangat liberalisme Barat.

Hanya saja perlu segera ditambahkan, jika peradaban Barat lahir dan bertumpu pada humanisme antroposentris, konsep humanisme Kuntowijoyo berakar pada humanisme teosentris. Karenanya, humanisasi tidak dapat dipahami secara utuh tanpa memahami konsep transendensi yang menjadi dasarnya.

Humanisme Barat lahir dari pemberontakan terhadap kekuasaan Gereja yang bersifat dogmatis pada abad Pertengahan. Pandangan antroposentris beranggapan bahwa kehidupan tidak berpusat pada Tuhan tapi pada manusia. Etosnya adalah semangat menghargai nilai-nilai yang dibangun oleh manusia sendiri.

Peradaban antroposentris menjadikan manusia sebagai tolok ukur kebenaran dan kepalsuan, untuk memakai manusia sebagai kriteria keindahan dan untuk memberikan nilai penting pada bagian kehidupan yang menjanjikan kekuasaan dan kesenangan manusia. Antroposentrisme menganggap manusia sebagai pusat dunia, karenanya merasa cukup dengan dirinya sendiri. Manusia antroposentris merasa menjadi penguasa bagi dirinya sendiri. Tidak hanya itu, ia pun bertindak lebih jauh, ia ingin menjadi penguasa bagi yang lain. Alam raya pun lalu menjadi sasaran nafsu berkuasanya yang semakin lama semakin tak terkendali.

Dengan rasio sebagai senjatanya, manusia antroposentris memulai sejarah kekuasaan dan eksploitasi atas alam tanpa batas. Modernisme dengan panjipanji rasionalismenya terbukti menimbulkan kerusakan alam tak terperikan terhadap alam dan manusia. Ilmu akal adalah ilmu perang yang metode dan taktik perangnya telah ditulis dengan amat cerdas oleh Descartes melalui semboyannya "Cogito Ergo Sum”.

Melalui ilmu perang Descartes, peradaban modern menciptakan mesinmesin perang terhadap alam berupa teknologi canggih untuk menaklukkan dan mengeksploitasi alam tanpa batas, juga mesin-mesin perang terhadap manusia berupa senjata-senjata canggih supermodern, bom, bahkan juga senjata pemusnah masal. Jadi, alih-alih humanisme antroposentris itu berhasil melakukan proses humanisasi, yang terjadi justru adalah proses dehumanisasi (Titus, 1990). 
Kuntowijoyo (1991) lalu mengusulkan humanisme teosentris sebagai ganti humanisme antroposentris untuk mengangkat kembali martabat manusia. Dengan konsep ini, manusia harus memusatkan diri pada Tuhan, tapi tujuannya adalah untuk kepentingan manusia (kemanusiaan) sendiri.

Perkembangan peradaban manusia tidak lagi diukur dengan rasionalitas tapi transendensi. Humanisasi diperlukan karena masyarakat sedang berada dalam tiga keadaan akut yaitu dehumanisasi (obyektivasi teknologis, ekonomis, budaya dan negara), agresivitas (agresivitas kolektif dan kriminalitas) dan loneliness (privatisasi, individuasi) (Kuntowijoyo, 1984).

Unsur kedua adalah liberasi. Liberasi adalah pemaknaan kreatif dari nahi munkar. Liberasi dalam Ilmu Sosial Profetik sesuai dengan prinsip sosialisme (marxisme, komunisme, teori ketergantungan, teologi pembebasan) (Kuntowijoyo, 1999).

Hanya saja Ilmu Sosial Profetik tidak hendak menjadikan liberasinya sebagai ideologi sebagaimana komunisme. Liberasi Ilmu Sosial Profetik adalah dalam konteks ilmu, ilmu yang didasari nilai-nilai luhur transendental. Jika nilai-nilai liberatif dalam teologi pembebasan dipahami dalam konteks ajaran teologis, maka nilai-nilai liberatif dalam Ilmu Sosial Profetik dipahami dan didudukkan dalam konteks ilmu sosial yang memiliki tanggung jawab profetik untuk membebaskan manusia dari kekejaman kemiskinan, pemerasan kelimpahan, dominasi struktur yang menindas dan hegemoni kesadaran palsu.

Lebih jauh, jika marxisme dengan semangat liberatifnya jutru menolak agama yang dipandangnya konservatif, Ilmu Sosial Profetik justru mencari sandaran semangat liberatifnya pada nilai-nilai profetik transendental dari agama yang telah ditransformasikan menjadi ilmu yang obyektif-faktual.

Bidikan liberasi ada pada realitas empiris, sehingga liberasi sangat peka dengan persoalan penindasan atau dominasi struktural. Fenomena kemiskinan yang lahir dari ketimpangan ekonomi adalah bagian penting dari proyek liberasi. Liberasi menempatkan diri bukan pada lapangan moralitas kemanusiaan abstrak, tapi pada realitas kemanusiaan empiris, bersifat kongkrit. Kuntowijoyo bahkan menganggap sikap menghindar dari yang kongkrit menuju abstrak adalah salah satu ciri berpikir berdasarkan mitos.

Kuntowijoyo menggariskan empat sasaran liberasi, yaitu sistem pengetahuan, sistem sosial, sistem ekonomi dan sistem politik yang membelenggu manusia sehingga tidak dapat mengaktualisasikan dirinya sebagai makhluk yang merdeka dan mulia (Kuntowijoyo, 1997). 
Transendensi adalah unsur ketiga Ilmu Sosial Propetik. Transendensi merupakan dasar dari dua unsurnya yang lain. Transendensi adalah konsep yang diderivasikan dari tu'minuna bi Allah (beriman kepada Allah). Transendensi hendak menjadikan nilai-nilai transendental (keimanan) sebagai bagian penting dari proses membangun peradaban. Transendensi menempatkan agama (nilai-nilai Islam) pada kedudukan yang sangat sentral dalam Ilmu Sosial Profetik.

Ekses-ekses negatif yang ditimbulkan oleh modernisasi mendorong terjadinya gairah untuk menangkap kembali alternatif-alternatif yang ditawarkan oleh agama untuk menyelesaikan persoalan-persoalan kemanusiaan. Manusia produk renaissance adalah manusia antroposentris yang merasa menjadi pusat dunia, cukup dengan dirinya sendiri.

Melalui proyek rasionalisasi, manusia memproklamirkan dirinya sebagai penguasa diri dan alam raya. Rasio mengajari cara berpikir bukan cara hidup. Rasio menciptakan alat-alat bukan kesadaran. Rasio mengajari manusia untuk menguasai hidup, bukan memaknainya. Akhirnya manusia menjalani kehidupannya tanpa makna.

Di sinilah transendensi dapat berperan penting dalam memberikan makna yang akan mengarahkan tujuan hidup manusia. Islam dapat membawakan kepada dunia yang sekarat, bukan karena kurang alat atau teknik, akan tetapi karena kekurangan maksud, arti dari masyarakat yang ingin merealisir rencana Tuhan. Nilai-nilai transendental ketuhanan inilah yang akan membimbing manusia menuju nilai-nilai luhur kemanusiaan.

Transendensi adalah dasar dari humanisasi dan liberasi. Transendensi memberi arah kemana dan untuk tujuan apa humanisasi dan liberasi itu dilakukan. Transendensi dalam Ilmu Sosial Profetik di samping berfungsi sebagai dasar nilai bagi praksis humanisasi dan liberasi, juga berfungsi sebagai kritik.

Dengan kritik transendensi, kemajuan teknik dapat diarahkan untuk mengabdi pada perkembangan manusia dan kemanusiaan, bukan pada kehancurannya. Melalui kritik transendensi, masyarakat akan dibebaskan dari kesadaran materialistikdi mana posisi ekonomi seseorang menentukan kesadarannya-menuju kesadaran transendental. Transendensi akan menjadi tolok ukur kemajuan dan kemunduran manusia.

Dari tiga pilar diatas, maka Kuntowijoyo menggiring umat Islam pada orientasi ilmu-ilmu sosial yang berparadigma Profetik. Dengan demikian kita dapat menggariskan beberapa hal. 
Pertama, sosiologi profetik memiliki tiga nilai penting sebagai landasannya yaitu humanisasi, liberasi dan transendensi. Ketiga nilai ini di samping berfungsi kritik juga akan memberi arah, bidang atau lapangan penelitian.

Kedua, secara epistemologis, sosiologi profetik berpendirian bahwa sumber pengetahuan itu ada tiga, yaitu realitas empiris, rasio dan wahyu. Ini bertentangan dengan positivisme yang memandang wahyu sebagai bagian dari mitos.

Ketiga, secara metodologis sosiologi profetik jelas berdiri dalam posisi yang berhadap-hadapan dengan positivisme. Sosiologi profetik menolak klaim-klaim positivis seperti klaim bebas nilai dan klaim bahwa yang sah sebagai sumber pengetahuan adalah fakta-fakta yang terindera. Sosiologi profetik juga menolak kecenderungan ilmu sosial yang hanya menjelaskan atau memahami realitas lalu memaafkannya. Sosiologi profetik tidak hanya memahami tapi juga punya cita-cita transformatif (liberasi, humanisasi dan transendensi).

Dalam pengertian ini sosiologi profetik lebih dekat dengan metodologi sosiologi kritis (teori kritis). Melalui liberasi dan humanisasi sosiologi profetik selaras dengan kepentingan emansipatoris sosiologi kritis. Bedanya sosiologi profetik juga mengusung transendensi sebagai salah satu nilai tujuannya dan menjadi dasar dari liberasi dan humanisasi.

Keempat, sosiologi profetik memiliki keberpihakan etis bahwa kesadaran (superstructure) menentukan basis material (structure) (Kuntowijoyo, 1991).

Barangkali yang menyebabkan Sosiologi Profetik menjadi problematis dan kontroversial adalah posisi epistemologisnya yang juga mengakui wahyu sebagai bagian sah dari sumber pengetahuan. Kontroversial, karena ilmu sosial modern sudah terlanjur mencampakkan wahyu dalam kategori mitos atau metafisika yang tidak mempunyai dasar empiris.

Problematis, karena ide ini dapat saja serta merta dipahami oleh para penganutnya dalam perspektif teologisnormatif, sehingga kita akan susah membedakan mana sosiologi mana teologi, mana empiris mana normatif. Dalam konteks ini, Sosiologi Profetik memiliki sebuah agenda besar: rekonstruksi epistemologis.

Rekonstruksi epistemologis itu Pertama, harus mampu membongkar akar-akar pemisahan wahyu dari wilayah ilmu pengetahuan dan selanjutnya membuktikan bahwa wahyu sesungguhnya dapat secara sah menjadi bagian dari epistemologi ilmu sosial. Dalam hal ini, tulisan Loay Safi kiranya sangat relevan. Safi mampu membuktikan melalui penelaahan 
terhadap sifat-sifat wahyu, rasionalitas, dan kualitas bukti yang diajukannya, bahwa penolakan terhadap wahyu sebagai sumber pengetahuan sesungguhnya didasarkan pada alasanalasan absurd dan artifisial, dibuat-buat dan bahwa konflik wahyu versus ilmu pengetahuan bukanlah konflik imperatif ataupun universal, tapi khas Barat. Karenanya, Louay Safi (2001) menyatakan, berbagai upaya untuk mereproduksi konflik ini dalam kebudayaan muslim adalah artifisial belaka dan didorong oleh keinginan irrasional untuk berjalan di atas landasan kebudayaan lain.

Kedua, rekonstruksi epistemologis juga harus mampu menyediakan dasardasar metodologis untuk dapat membawa masuk wahyu ke dalam kancah ilmu sosial. Untuk keperluan ini, pendekatan teologis-normatif yang selama ini telah begitu hegemonik di benak kita harus dirubah ke arah pendekatan empiris-faktual. Orientasi teks harus dirubah ke arah orientasi realitas. Gagasan Kuntowijoyo tentang methodological objectivism atau obyektifikasi dapat dipahami dalam konteks ini (Susanto, 2003).

\section{Nilai-Nilai Pendidikan Profetik}

Hubungan antara nilai dengan pendidikan sangat erat. Nilai dilibatkan dalam setiap tindakan pendidikan, baik dalam memilih maupun dalam memutuskan setiap hal untuk kebutuhan belajar. Melalui persepsi nilai, pendidik dapat mengevaluasi peserta didik. Demikian pula peserta didik dapat mengukur kadar nilai yang disajikan pendidik dalam proses pembelajaran. Masyarakat juga dapat merujuk sejumlah nilai (benar-salah, baik-buruk, indahtidak indah) ketika mereka mempertimbangkan kelayakan pendidikan yang dialami anaknya.

Lembaga pendidikan memiliki tugas mempersiapkan terbentuknya individu-individu yang cerdas dan berakhlak mulia. Terpenuhinya kedua kriteria itu memungkinkan terwujudnya nilai kehidupan sosial yang ideal, yang memiliki semangat kebersamaan, menghindari konflik sosial, mengembangkan potensi diri, dan memanfaatkannya untuk mencapai kebahagiaan lahir dan batin, serta keselamatan umat manusia pada umumnya (Fadjar, 1999).

Hal tersebut menunjukkan bahwa peran pendidikan dalam pembentukan dan penanaman nilai terhadap peserta didik sangat menentukan kehidupan mereka. Tanpa pendidikan, nilai sangat sulit untuk ditemukan atau didapatkan. Oleh karena itu, fungsi pendidikan adalah untuk menanamkan nilai-nilai (yang baik) kepada peserta didik (bukan hanya transfer pengetahuan) sebagaimana yang popular selama ini. Pengetahuan tanpa memahami nilai cenderung melahirkan konflik, baik 
antar-kelompok agama, budaya, wilayah, maupun antar-institusi.

Konflik-konflik yang muncul di tanah air akhir-akhir ini sangat terkait dengan aspek sosial, budaya, dan agama. Menurut penulis, hal ini disebabkan lemahnya peran pendidikan yang menanamkan nilai kebersamaan dan solidaritas sosial dalam era pluralitas.

Untuk memahami nilai-nilai pendidikan profetik, terlebih dahulu penulis kemukakan pengertian nilai. Istilah nilai memiliki banyak pengertian, tergantung dari sudut pandang mana seseorang memahami. Sosiolog, antropolog, psikolog, ekonom, serta politisi mempunyai persepsi dalam memaknai nilai. Pada intinya, memahami nilai itu bersifat subjektif. Dalam tulisan ini, nilai diartikan sebagai penentu seseorang dalam melakukan suatu tindakan yang positif atau nilai dapat juga disebut perilaku moral.

Nilai adalah rujukan dan keyakinan dalam menentukan suatu pilihan (Mulyana, 2004). Oleh karena nilai sebagai rujukan dalam bertindak, maka setiap orang harus memperhatikan lebih mendalam agar hati-hati dan berpikir rasional sebelum mengambil tindakan. Seseorang yang bertindak tanpa dasar rujukan yang kuat dapat dianggap tidak memiliki dan memahami nilai moral.

Menurut Judy Lawly (2000), nilai merupakan pedoman kepercayaan yang mendalam mengenai suatu hal yang penting. Nilai secara langsung mempengaruhi perilaku dan tertanam kuat dalam kebudayaan masyarakat dan latar belakang keluarga.

Schwartz (2002) mendefinisikan "values as goals and motivations which serve as guiding principles in people's lives". Artinya, nilai sebagai tujuan dan motivasi yang berperan sebagai prinsip-prinsip petunjuk dalam kehidupan manusia. Apabila nilai telah mempribadi dalam kehidupan seseorang, maka akan tampak dalam pola-pola sikap, niat dan perilakunya.

Sedangkan menurut Merril (dalam Koyan, 2000), nilai adalah patokan atau standar pola-pola pilihan yang dapat membimbing seseorang atau kelompok ke arah "satisfaction,fulfillment, and meaning”. Patokan, kriteria, prinsipprinsip, dan ukuran yang memberi dasar pertimbangan kritis tentang pengertian, estetika, kewajiban moral, dan religius.

Jadi, nilai-nilai pendidikan adalah nilai-nilai yang harus ditanamankan dan dikemmbangkan pada diri seseorang. Mardiatmaja mengemukakan nilai-nilai pendidikan sebagai bantuan terhadap peserta didik agar menyadari dan mengalami nilai-nilai serta menempatkannya secara integral dalam keseluruhan hidupnya.

Dengan demikian, nilai-nilai pendidikan tidak hanya merupakan program khusus yang diajarkan melalui sejumlah mata pelajaran, tetapi 
mencakup pula keseluruhan proses pendidikan. Dalam hal ini, yang menanamkan nilai kepada peserta didik bukan saja guru pendidikan nilai dan moral serta bukan saja pada saat mengajarkannya, melainkan kapan dan di manapun, nilai harus menjadi bagian integral dalam kehidupan.

Dari definisi di atas dapat ditarik suatu definisi nilai-nilai pendidikan mencakup keseluruhan aspek pengajaran atau bimbingan kepada peserta didik agar memiliki modal nilai yang menjadi prinsip dan petunjuk dalam kehidupannya. Dengan demikian, mereka menyadari nilai kebenaran, kebaikan, kebersamaan, dan keindahan melalui proses pertimbangan nilai yang tepat dan pembiasaan bertindak yang konsisten.

Penekanannya terletak pada peran pendidikan sebagai transformasi nilai sehingga menjadi bagian yang integral dalam diri peserta didik. Dengan memiliki nilai moral, maka segala tindakan peserta didik akan terkontrol karena dilakukan dengan pertimbangan nilai yang matang.

Berikut adalah nilai-nilai yang dikembangkan oleh Kuntowijoyo, yang menjadi basis dalam pendidikan Profetik;

\section{Humanisasi}

Dalam bahasa agama, konsep humanisasi adalah terjemahan kreatif dari amar al ma'ruf yang makna asalnya menganjurkan menegakkan kebajikan. Dalam bahasa ilmu, secara etimologi, humanisasi berasal dari bahasa latin humanitas yang artinya "makhluk manusia", "kondisi menjadi manusia”. Secara terminologi berarti memanusiakan manusia, menghilangkan kebendaan, ketergantungan, kekerasan, dan kebencian dari manusia (Kuntowijoyo, 1991).

Berdasarkan pemahaman tersebut, menurut Kuntowijoyo, konsep humanisasi ini berakar pada bumanisme-teosentris, oleh sebab itu tidak dapat dipahami secara utuh tanpa memahami konsep transendensi yang menjadi dasarnya. Humanisme-teosentris, maksudnya adalah manusia harus memusatkan diri kepada Tuhan, tetapi tujuannya adalah untuk kepentingan manusia sendiri. Maksudnya, keyakinan religius yang berakar pada pandangan teosentris, selalu dikaitkan dengan amal atau perbuatan manusia, keduanya merupakan satu kesatuan yang tak terpisahkan. Ia berpandangan, bumanisme-teosentris inilah yang merupakan nilai inti (corevalue) dari seluruh ajaran Islam (Kuntowijoyo, 1999).

Menurut Ali Syari'ati, dalam khazanah filsafat barat, dikenal adanya filsafat humanisme yang menyatakan oposisi terhadap filsafatfilsafat keagamaan (didasari oleh kepercayaan yang serba ghaib dan 
supranatural) yang bertujuan untuk memulihkan martabat manusia.

$$
\text { Ali Syari'ati }
$$

menambahkan, filsafat humanisme (barat) berpandangan bahwa tidak ada dewa-dewa, tidak ada hubungan antara manusia dengan surga, serta menitikberatkan pada alam antroposentris atau untuk menjadikan manusia sebagai batu ujian kebenaran dan kepalsuan, serta memakai manusia sebagai kriteria keindahan dan untuk memberikan nilai keindahan pada bagian kehidupan yang meningkatkan kekuatan dan kesenangan manusia. (Syariati, 1982). Dengan kata lain, manusia menjadi pusat kebenaran etika, kebijaksanaan, dan pengetahuan. Manusia adalah pencipta, pelaksana, dan konsumen produk-produk manusia sendiri.

Menurut Ali Syari'ati (1996), humanisme adalah ungkapan dari sekumpulan nilai Ilahiah yang ada dalam diri manusia yang merupakan petunjuk agama dan moral manusia, yang tidak berhasil dibuktikan adanya oleh ideologiideologi modern akibat pengingkaran mereka terhadap agama.

Dalam pandangan Erich Fromm, manusia saat ini memasuki revolusi industri tahap dua yang bukan hanya mengganti energi hidup dengan mesinmesin, tapi pikiran manusia pun diganti oleh mesinmesin. Dengan pikirannya, manusia menciptakan mesin-mesin untuk mengganti pikirannya sendiri. Ketika mesin-mesin sudah menguasai pikiran manusia, secara tidak sadar manusia saat ini telah berhenti menjadi manusia, beralih menjadi robot-robot yang tidak berpikir atau pikirannya dikendalikan dan tidak berperasaan (Fromm, 1996). Jika begitu, maka teknologi yang seharusnya menjadi alat kemanusiaan untuk melepaskan diri dari perbudakan kerja, justru berubah menjadi suatu mekanisme yang memperbudak manusia sendiri.

Menurut penulis, pandangan Kuntowijoyo yang mengusulkan bumanisme-teosentris sebagai ganti bumanisme-antroposentris dalam pandangan barat menjadi salah satu alternatif dalam menghadapi globalisasi dengan arus industrialisasinya.

Menurut Kuntowijoyo (1993) Jika selama ini humanisme ditentukan oleh nilai- nilai antroposentris yang diukur dengan rasionalitas, maka dengan bumanismeteosentris, kemanusiaan tidak lagi diukur dengan rasionalitas, tetapi dengan transendensi. Transendensilah yang akan mengembalikan dimensi makna dan tujuan yang telah hilang dari kehidupan manusia teknokratis. 
Salah satu efek industrialisasi menurut Kuntowijoyo adalah terbentuknya masyarakat abstrak, masyarakat tanpa wajah kemanusiaan. (Kuntowijoyo, 1991), Manusia telah menjadi robot alias mesin-mesin industri. Manusia telah mengalami obyektivasi ketika berada di tengah-tengah mein- mesin politik dan mesin-mesin pasar. Kemajuan ilmu dan teknologi, disadari atau tidak, juga telah membantu kecenderungan reduksionistik yang melihat manusia dengan cara parsial. Maka menjadi tepat apa yang dikatakan Kuntowijoyo, bahwa tujuan humanisasi adalah memanusiakan manusia.

$$
\text { Apa yang dikatakan }
$$

Kuntowijoyo di atas telah disinyalir oleh Ali Syar'ati (1982), bahwa mesin-mesin sebagai hasil sains yang semula menjadi alat bagi manusia untuk menjadikannya penguasa atas alam dan dibebaskan dari perbudakan kerja, kini berubah menjadi sistem mekanis yang membelenggu manusia. Manusia telah me njadi bulan-bulanan dari sistem mekanis yang berat dan kejam dengan kepemimpinan teknobirokratis yang tidak mengenal belas kasihan.

Senada dengan Syari'ati, Imam Tholkhah (2004) menyebut salah satu efek modernisasi global (salah satu tandanya adalah industrialisasi yang massif) adalah menggiring manusia ke arah alienasi, yaitu sebuah kondisi manusia yang asing dari kesejatian diri dan lingkungannya, manusia jatuh menjadi pribadipribadi yang miskin spiritual, dan terjebak dalam lembah material individualistis.

Kuntowijoyo menambahkan, musuh humanisasi lainnya adalah agresivitas kolektif. Ia mencontohkan kerusuhan massal yang dilakukan oleh mass man (manusia massa) yang terjadi di Indonesia akhir-akhir ini dengan berbagi macam sebabnya. Menurutnya, ini disebabkan oleh kekumuhan material yang berkembang menjadi kekumuhan spiritual. Humanisasi berusaha mencegah agar kekumuhan material tidak berkembang menjadi kekumuhan spiritual (Tholkhah, 2004).

Aspek lain yang menjadi titik tuju dari humanisasi adalah loneliness (privatisasi, individuasi), yang saat ini sudah menggejala dalam masyarakat kota. Misalnya dalam lingkup kecil, tak jarang ada keluarga yang tak mengetahui perihal tetangganya. Pola hidup sendiri dan cenderung mengacuhkan masyarakat sekitarnya ini biasanya dapat kita lihat pada masyarakat menegah ke atas. Menurut Kuntowijoyo, meskipun orang kota hidup bergerombol, 
sebenarnya mereka hidup sendirisendiri.

Saat ini, yang masih punya fungsi melawan loneliness kota adalah adanya pengajian, pertemuan PKK, karang Taruna, dan anjangsana tingkat RT/RW. Kuntowijoyo menambahkan perlunya usaha untuk mengangkat kembali martabat (emansipasi) manusia, bumanization (menurut Fromm, 1968), karena manusia dalam zaman industri mudah sekali terjatuh atau kehilangan kemanusiaannya.

Revolusi industri yang saat ini merambah pada revolusi sains dan teknik yang luar biasa telah menimbulkan problem-problem moral yang belum pernah terjadi. Maka diperlukan adanya bimbingan supaya manusia mampu menuju nilai-nilai luhur kemanusiaan, yang di satu sisi mendapatkan maknanya dari nilai- nilai transendensi.

Jika dalam Al-Qur'an Surat AtTin ayat 5-6 dikatakan bahwa manusia itu mudah terjatuh ke tempat yang paling rendah, kecuali orang-orang yang beriman dan beramal saleh, maka menurut Kuntowijoyo (1991) ini adalah ayat humanisasi, yaitu iman dan amal saleh yang mempunyai implikasi sangat luas, segala prilaku manusia yang membawa kearah mengangkat martabat manusia.
Dalam konteks pendidikan, humanisasi ini berarti pendidikan yang mengajarkan anti-kekerasan (Susanto, 2004). Sebuah konsep pendidikan yang mampu membangun kepribadian manusia yang berkarakter terbuka, manusiawi, dan memiliki kesadaran yang tinggi ketika harus menghadapi realitas yang diliputi bertumpuk persoalan (Susanto, 2004).

\section{Liberasi}

Liberasi dalam pandangan Kuntowijoyo (1991) adalah bahasa ilmu dari nabi munkar. Jika dalam bahasa agama nabi munkar artinya mencegah dari segala tindak kejahatan yang merusak, memberantas judi, lintah darat, korupsi, dan lainnya, maka dalam bahasa ilmu, nabi munkar artinya pembebasan dari kebodohan, kemiskinan, ataupun penindasan.

Secara etimologi, liberasi berasal dari bahasa latin liberare yang artinya memerdekakan. Secara istilah, liberasi dapat diartikan dengan pembebasan, semuanya dengan konotasi yang mempunyai signifikansi sosial (Kuntowijoyo, 1999).

Liberasi yang dimaksud Kuntowijoyo dalam Ilmu Social Profetik adalah dalam konteks ilmu, yang didasari nilai-nilai luhur transendental. Nilai-nilai liberatif 
dalam ISP dipahami dan didudukkan dalam konteks ilmu sosial yang memiliki tanggung jawab profetik.

$\begin{array}{ccc}\text { Tujuan } & \text { liberasi } & \text { dalam } \\ \text { pandangan } & \text { Kuntowijoyo } & (1991)\end{array}$ adalah pembebasan manusia dari kekejaman pemiskinan struktural, keangkuhan teknologi, pemerasan kelimpahan, dominasi struktur yang menindas, dan hegemoni kesadaran palsu. Semangat liberatif ini dicari pada nilai- nilai profetik transendental dari agama yang telah ditransformasikan menjadi ilmu yang obyektif- faktual.

\section{Liberasi perspektif} Kuntowijoyo (1997) mengambil semangat dari teologi pembebasan, yang mempunyai empat sasaran utama, yaitu liberasi dalam sistem pengetahuan, sistem sosial, sistem ekonomi, dan sistem politik yang membelenggu manusia sehingga tidak dapat mengaktualisasikan dirinya sebagi makhluk yang merdeka dan mulia.

Menurut M. Amien Rais (1998), pemahaman teologi harus dirubah, menurutnya teologi hendaknya tidak lagi berbicara mengenai ketuhanan saja, melainkan teologi lebih dari itu, yaitu juga berbicara tentang hubungan antara ketuhanan us kontekstual yang betulbetul mampu memecahkan masalahmasalah kemasyarakatan yang sedang kita hadapi, misalnya membuat pembebasan terhadap setiap gejala eksploitasi dalam masyarakat, kemudian juga memberi santunan lepada anak-anak yatim dan memperhatikan nasib kaum fakir miskin.

Konsep teologi yang kontekstual ini, dalam pandangan penulis akan mampu mewujudkan kesalehan sosial. Kesalehan sosial ini, meminjam pendapat Khozin (2004) merupakan wujud dari pemahaman keberagamaan secara ekstrinsik, pemahaman keberagamaan yang tidak hanya menyentuh bagian luar (kulit) dari ajaran Islam, tapi juga menemukan daging (isi) ajaran Islam yang sesungguhnya.

Liberasi dalam sistem pengetahuan menurut Kuntowijoyo (1991) adalah usaha-usaha untuk membebaskan orang dari sistem pengetahuan materialistik, dari dominasi struktur, misalnya kelas dan seks. Karena dalam ajaran Islam tidak mengenal adanya struktur atau perbedaan kelas sosial dalam masyarakat. Ajaran Islam juga mengandung suatu moderasi, yaitu kemitrasejajaran antara pria dan wanita dengan perspektif gender (Kuntowijoyo, 1991).

Menurut Kuntowijoyo (1991), the great transformation bagi umat Islam saat ini adalah transformasi sosial 
umat dari sistem sosial agraris menuju sistem soiial industrial. Oleh karena itu pembebasan dari sistem sosial yang membelenggu menjadi amat penting.

Dari pandangan Kuntowijoyo di atas, belenggu sistem social berpengaruh dalam transformasi umat. Jika belenggu tidak dilepaskan, maka umat Islam akan kesulitan dalam beradaptasi dengan perkembangan dunia modern. Jika demikian, efek selanjutnya adalah umat tidak akan pernah maju, akan terpinggirkan, hanya jalan di tempat atau bahkan melangkah mundur.

Persoalan umat Islam yang semakin tren ke depan akan lebih banyak berkutat pada persoalan sosial. Ketimpangan sosial, misalnya kemiskinan struktural, penindasan terhadap kaum mustadh'afin (kaum tertindas), menuntut kepedulian segenap elemen umat Islam.

Di sini agama harus mengambil peran. Meminjam pendapat Moeslim Abdurrahman (2003), bahwa agama harus berani lebur memihak kepada ajaran tauhid sosial dengan misinya yang paling esensial adalah sebagai kekuatan emansipatoris yang selalu peka terhadap penderitaan kaum tertindas.

Pembebasan dari belenggu sistem ekonomi juga menjadi sasaran lanjutan dari liberasi. Sistem ekonomi yang menyuburkan kesenjangan, memperbesar disparitas (jarak) antara si kaya dan si miskin, sudah satina dikubur dalam-dalam. Islam menentang kondisi seperti ini. Umat Islam, menurut Kuntowijoyo harus mampu menyatu rasa dengan mereka yang miskin, mereka yang terperangkap dalam kesaadaran teknokratis, dan mereka yang tergusur oleh ekonomi raksasa (Abdurrahman, 2003).

Islam sebenarnya bersifat afirmatif terhadap upaya-upaya pembebasan dari sistem ekonomi yang tidak adil, sistem ekonomi yang menindas dan menguntungkan sekelompok kecil. Dalam pandangan Kuntowijoyo, ini menemukan dasarnya dalam Al-Qur'an Surat AlHasyir ayat 7 yang menyatakan bahwa Islam melarang harta kekayaan yang hanya beredar di kalangan orang kaya di antara umatnya (Abdurrahman, 2003).

Selanjutnya, liberasi politik berarti membebaskan sistem politik dari otoritarianisme, kediktatoran, dan neofeodalisme. Menurut Kuntowijoyo (1991), demokrasi, Hak Asasi Manusia (HAM), dan masyarakat madani adalah juga tujuan Islam. Terkait dengan pembebasan sistem politik ini, menurutnya seorang intelektual Islam tidak boleh takut ber-nabi munkar asal dilandasi dengan ilmu. 
Di sini tampak, bahwa ada beban yang terpikul di pundak intelektual muslim untuk selalu mengawasi dan korektif terhadap penyimpangan dalam kehidupan politik, yang merugikan kepentingan umat.

$$
\text { Hassan Hanafi }
$$

menyatakan bahwa salah satu paradigma dari teologi pembebasan adalah pembebasan melalui teologi, untuk kepentingan manusia itu sendiri. Dalam pandangan penulis, teologi-teologi atau keyakinan keagamaan haruslah menjadi landasan dari praksis perbaikan umat manusia. Manusia harus dibebaskan dari segala struktur dalam berbagai bidang yang bersifat menindas dan mengekang kebebasan.

Dalam konteks pendidikan, konsep pendidikan yang membebaskan ini, sering merujuk pada pemikiran Paolo Freire, seorang mahaguru filsafat dan ilmu pendidikan dalam refleksi kritisnya terhadap sistem pendidikan di Brazil, ia pun mempersoalkan taqlid sebagai salah satu faktor yang melanggengkan bahkan memperparah penindasan rakyat miskin oleh penguasa. Freire menyebut metode seperti ini sebagai metode pendidikan gaya banking yang menindas (Dhakiri, 2000).

\section{Transendensi}

Transcendere, adalah bahasa latin transendensi yang artinya 'naik ke atas'. Dalam bahasa Inggris adalah to transcend yang artinya 'menembus', 'melewati', 'melampaui'. Menurut istilah artinya perjalanan di atas atau di luar. Yang dimaksud Kuntowijoyo (1991) adalah transendensi dalam istilah teologis, yakni bermakna ketuhanan, makhluk-makhluk gaib.

Tujuan transendensi adalah untuk menambahkan dimensi transendental dalam kebudayaan, membersihkan diri dari arus hedonisme, materialisme, dan budaya yang dekaden. Dimensi transendental adalah bagian sah dari fitrah kemanusiaan sebagai bentuk persentuhan dengan kebesaran Tuhan.

Jika banyak yang sepakat bahwa abad ke-21 adalah peradaban postmodernisme, maka salah satu ciri dari postmodernisme adalah semakin menguatnya spiritualisme, yang salah satu tandanya adalah dedifferentiation, yaitu agama akan menyatu kembali dengan 'dunia'.

Bagi umat Islam, dedifferentiation ini bukanlah hal yang baru, mengingat dalam Islam sendiri tidak meletakkan urusan akhirat tersendiri, dan urusan dunia terpisah sendiri juga. Bagi orang Islam, urusan dunia, eksistensi selama hidup di dunia akan 
mempengaruhi kehidupan akhirat kelak. Amal di dunia bukan hal yang sia-sia yang tidak akan pernah diperhitungkan, tapi akan mendapatkan balasan di kehidupan akhirat. Oleh karena itu, menurut Kuntowijoyo (1991), sudah selayaknya jika umat Islam meletakkan Allah SWT sebagai pemegang otoritas, Tuhan Yang Maha Obyektif, dengan 99 Nama Indah itu.

Jika manusai tidak menerima Tuhan sebagai otoritas, maka akan tampak: 1) relativisme penuh, dimana nilai dan norma seepnuhnya adalah urusan pribadi, 2) nilai bergantung pada masyarakat, sehingga nilai dari golongan yang dominan akan menguasai, dan 3) nilai bergantung pada kondisi biologis, sehingga Darwinisme sosial, egoisme, kompetisi, dan agresivitas adalah nilai- nilai kebajikan (1968: 87-88).

Dalam paparan di atas, nilainilai humanisasi dan liberasi harus bertitik pangkal dari nilai- nilai transendensi. Kerja kemanusiaan dan kerja pembebasan harus didasarkan pada nilai-nilai keimanan kepada Allah SWT. Nilai transendensi menghendaki umat Islam meletakkan posisi Allah SW'T sebagai pemegang otoritas tertinggi.
Dalam perspektif Roger Garaudy (1986), bahwa transendensi menghendaki kita mengakui keunggulan norma-norma mutlak yang melampaui akal manusia.

Konsep transendensi Kuntowijoyo ini dalam pandangan penulis senada dengan konsep transendensi dari Hassan Hanafi. Hassan Hanafi (menyatakan bahwa transenden bukanlah keimanan yang simple tanpa usaha, bukan juga sebuah penerang internal untuk keindahan spiritual dan pengindahan mistik, tetapi ia adalah sebuah perjuangan permanen antara akal dan keinginan, kebaikan dan kejahatan, persatuan dan perbedaan, perdamaian dan perselisihan, konstruksi dan destruksi, kehidupan dan kematian. ${ }^{1}$

Para nabi pun masuk ke wilayah perjuangan politik, ekonomi, pendidikan, dan lainnya di masa lalu dengan berdasarkan pada nilai- nilai transenden ini dengan landasan keimanan dan penyerahan total kepada Allah SWT.

\section{Penutup}

Selama ini, model pembelajaran di sekolah, selalu dinilai dengan muatanmuatan yang terkesan memaksa dan

\footnotetext{
${ }^{1}$ Hassan Hanafi, Bongkar Tafsir, hlm.
} 114 
menakutkan peserta didik. Ketika peserta didik melakukan kesalahan, maka yang muncul adalah ancaman dan hukuman, serta selalu dinilai dengan angka-angka. Pendidikan Islam jarang mengajak peserta didik untuk memahami secara hakiki tentang firman-firman Allah, bahkan tidak pernah mengajak mereka untuk memahami cinta Allah. Pembelajaran tentang cinta Allah, akan menyentuh hati dan mengembangkan sikap-sikap empati dan simpati terhadap sesama. Menyantuni saudara, teman, bahkan menyantuni hewan dan tanaman, merupakan bagian yang esensial dari kehadiran Allah di alam semesta ini.

Pembelajaran cinta Allah ini, justru akan melahirkan sikap penghayatan seseorang tentang Tuhan (transendendsi). Sebuah kesadaran dimana Tuhan akan selalu menyertai manusia disetiap saat, Tuhan selalu hadir dalam hidup manusia, dan Tuhan selalu mengawasi setiap tingkah laku manusia : "kemanapun kamu berada, maka disanalah wajah Tuban...” (QS. Al-Baqarah : 115), "Dia beserta kamu kemanapun kamu berada, dan Dia mengetahui segala sesuatu yang kamu perbuat." (QS. Al-Hadid : 4). Apabila kesadaran ini, selalu diasah dalam jiwa peserta didik, maka kehendak untuk selalu menjaga diri dari perbuatan keji akan selalu muncul. Sehingga rasa atau kesadaran ketuhanan ini akan berimplikasi kepada kesadaran kemanusiaan ; amal shalib, al-akblaq alkarimah, dan lainnya
Pendidikan Islam sebenarnya tidak terbatas hanya kepada pengajaran tentang ritus-ritus dan segi-segi formalitasnya. Hal ini, bukan berarti pengingkaran terhadap pentingnya ritusritus dan segi-segi formalistic agama. Jadi pendidikan Islam sesungguhnya adalah pendidikan untuk pertumbuhan total seorang peserta didik.

Jadi yang menjadi titik tekannya dalam pendidikan agama adalah membangun nilai-nilai ketuhanan; seperti iman, Islam, Ibsan, dan seterusnya, dan nilai-nilai moral; seperti kasih sayang, cinta, toleransi, tenggang rasa, kebajikan, menghargai perbedaan pendapat, dan sikap-sikap kemanuisaan yang mulia lainnya. Materi agamaan di gali melalui nilai-nilai universal dari sebuah agama. Dari tulisan ini, maka menjadi catata penting adalah : Pertama, menjadikan nilai-nilai pendidikan profetik sebagai upaya untuk menciptakan pendidikan Islam yang penuh cinta, toleransi, tenggang rasa, kebajikan, menghargai perbedaanm dan sikap-sikap kemanusiaan lainnya. Kedua, Pendidikan Islam semestinya mewarisi misi kenabian Muhammad sebagai model dalam proses pembelajaran. Yaitu mendasarkan diri pada kesadaran bahwa pendidikan Islam mengajarkan akan kearifan; setiap prilaku manusia didasarkan pada aturan dan tuntunan Tuhan. Ketiga, Ilmu tidak lah semestinya diposisikan secara dikotomis. Semua ilmu, pasti mempunyai nilai-nila universalitas yang luhur. Oleh 
sebab itu, obektifikasi dalam memandang sebuah ilmu menjadi sangat penting..

\section{DAFTAR PUSTAKA}

Ali Syari'ati, Tentang Sosiologi Islam (terj. Saifullah Mahyudin) (Yogyakarta: Ananda, 1982), Ali Syari'ati, Humanisme: Antara Islam dan Mazhab Barat (terjemahan) (Bandung: Pustaka Indah, 1996)

A. Malik Fadjar, Reorientasi Pendidikan Islam (Jakarta: Fajar Dunia, 1999).

Erich Fromm, Revolusi Harapan: Menuju Masyarakat Teknologi yang Manusiawi, terj.: Kamdani (Yogyakarta: Pustaka Pelajar, 1996)
Happy Susanto, "Menggagas "Sosiologi Profetik": Sebuah Tinjauan Awal", dalam Jurnal Pemikiran Islam Vol.1, No.2, Juni 2003.

Husnul Muttaqin, "Sosiologi Profetik" dalam Jurnal Sosiologi Reflektif, edisi Perdana, Prodi Sosiologi Fak. Ilmu Sosial dan Humaniora UIN Sunan Kalijaga Jogjakarta, Tahun 2005

Happy Susanto, "Menuju Pendidikan yang Humanis", dalam Jurnal Moderate Center for Moderate Muslim (CMM), Jakarta, 31August-2004

Hassan Hanafi, Bongkar Tafsir:Liberalisasi, Revolusi, Hermeneutik (terjemahan) (Jogjakarta: Prismasophie, 2005)

Imam Tholkhah dan Ahmad Barizi, Membuka Jendela Pendidikan: Mengurai Akar Tradis dan Integrasi Keilmuan Pendidikan Islam (Jakarta: raja Grafindo Persada, 2004)

I Wayan Koyan, Pendidikan Moral Pendekatan Lintas Budaya (Jakarta: Dirjend Dikti Depdiknas, 2000)

Kuntowijoyo, "Maklumat Sastra Profetik" dalam Horison, Mei 2005

$\longrightarrow$ Islam sebagai Ilmu; Epistemologi, Metodologi, dan Etika. Jakarta : TERAJU, 2004)

"Paradigma Baru Ilmuilmu Islam: Ilmu Sosial Profetik Sebagai Gerakan Intelektual", Jurnal Mukaddimah (Nomor 7, Tahun V/1999) , "Menuju Ilmu Sosial Profetik", Republika Agustus 1997) , Menuju Ilmu Sosial Profetik, Republika (19 Agustus 1997) 
Dinamika Sejarah Umat Islam di Indonesia, (Yogyakarta: Pustaka Pelajar, 1994) , Dinamika Internal Umat Islam Indonesia (Jakarta: LSIP, 1993),

Paradigma. Islam: Interpretasi Untuk Aksi, Bandung : Mizan, 1991

"Islam Sebagai Ide", Prisma, No. Ekstra, 1984

Khozin, Refleksi Keberagamaan Dari Kepekaan Teologis Menuju Kepekaan Sosial (Malang: UMM Press, 2004)

Louay Safi, Ancangan Metodologi Alternatif: Sebuab Refleksi Perbandingan Metode Penelitian Islam dan Barat, (The Foundation of Knowladge: $A$ Comparative Study In Islamic and Western Methodes of Inquiry ), alih bahasa Imam Khoiri, Yogyakarta : Tiara Wacana, 2001.

L. Myyry \& K. Helkama, "The Role of Value Priorities and Professional Ethics Training Moral Sensitivity", dalam The Journal of Moral Education, Volume 31 Number 1 March, 2002

Made Pramono, "Menyelami Spirit Epistemologi Paolo Freire", dalam: Listiyono Santoso \& Sunarto dkk, Epistemologi Kiri, (Yogyakarta : Ar-Ruz, 2003),

Mardiatmadja, Tantangan Dunia Pendidikan (Yogyakarta: Kanisius, TT)

Moeslim Abdurrahman, Islam Sebagai Kritik Sosial (Jakarta: Erlangga, 2003)

Muh. Hanif Dhakiri, Paolo Freire, Islam dan Pembebasan, (Bandung : Djambatan, 2000),

M. Amien Rais, Taubid Sosial: Formula Menggempur Kesenjangan (Bandung: Mizan, 1998)
M. Fahmi, Islam Transendental: Menelusuri Jejak-jejak Pemikiran Islam Kuntowijoyo (Yogyakarta: Pilar Religia, 2005),

Rochmat Mulyana, Mengartikulasikan Pendidikan Nilai (Bandung: Alfabeta, 2004)

Roger Garaudy, Mencari Agama pada Abad XX: Wasiat Filsafat Roger Garaudy (Jakarta: Bulan Bintang, 1986)

Shofiyullah Mz., "Paradigma Pemikiran Islam Kuntowijoyo", Makalah Annual Conference on Islamic Studies (ACIS) ke-7 di Pekanbaru - Riau, pada tanggal 24 - 26 November 2007

Sudarminta, "Pendidikan Moral di Sekolah Jalan Keluar Mengatasi Krisis Bangsa" dalam Tonny D. Widiastono (Ed), Pendidikan Manusia Indonesia (Jakarta: Kompas, 2004)

Yuyuk Sugarman, "Akhirnya, Kuntowijoyo Berjalan di Atas Mega", dalam Harian Sinar Harapan, Eddisi, 1 April 2009, 